\title{
Historiography of Ket Language
}

\author{
Anastasia V. Kistova and Natalia N. Pimenova* \\ Siberian Federal University \\ 79 Svobodny, Krasnoyarsk, 660041, Russia
}

Received 06.03.2018, received in revised form 30.03.2018, accepted 03.04.2018

\begin{abstract}
The present article describes the history of research of small-numbered indigenous peoples of the North and Siberia, and Ket language in particular. It determines the main stages of Ket language studies: pre-Revolution, Soviet and contemporary periods. Along with that, the results of expeditions intended to explore the problems of existence and opportunities of preserving Ket language are presented. The results of Ket language studies carried out by different specialists are described. The authors arrive at the conclusion on the current situation of this field of study in Siberia, Russia and beyond, consider the possible prospects of the research.
\end{abstract}

Keywords: Languages of the small-numbered indigenous peoples of the North and Siberia, Ket language, field studies, ethnographer linguists.

The reported study was funded by Krasnoyarsk Regional Fund of Science according to the research project: "Development of scientific and methodological support for the preservation of a unique cultural heritage for the Ket and Enets ethno-cultural groups of indigenous small peoples of the North, Siberia and the Far East living on the territory of the Krasnoyarsk Territory.

DOI: 10.17516/1997-1370-0247.

Research area: culturology.

\section{Introduction}

The interest for the languages of smallnumbered indigenous peoples of the North and Siberia goes back to the scientific and geographic expeditions of the $18^{\text {th }}$ century. The first descriptions of the indigenous peoples, their culture and lifestyle refer to that period of time. Thus, the first information of Ket language is found in the monograph by P.S. Pallas "A Travel Through Various Provinces of the Russian Empire", created upon the results of the expedition carried out in the years 1768-1774 under the aegis of the Russian Academy of Sciences (Pallas, 1786).
In the $19^{\text {th }}$ century, as the term of ethnos got scientifically formulated, specific ethnographic expeditions were organized to collect descriptions of the indigenous languages among other information. The first grammar and dictionary of Ket language were published by German researcher M.A. Castrén, in the year 1858 (Castrén, 1858).

However, according to various researchers, the greatest contribution to the studies and preservation of the languages of small-numbered indigenous peoples of the North and Siberia was made during the Soviet period. In the years

(C) Siberian Federal University. All rights reserved

* Corresponding author E-mail address: kistochka7@mail.ru; pimenovapluzhnik@mail.ru 
1934, N.K. Karger created and published the first Ket language $\mathrm{ABC}$ book (Karger, 1934). In the year 1967, E.A. Alexeenko wrote a fundamental historical and ethnological research of the Ket people (Alexeenko, 1967). Thanks to the efforts of A.P. Dul'zon and his successors, the School of Indigenous Peoples of the North and Siberia, still functioning nowadays, was opened in Tomsk (Dul'zon, 1968, 1972, 1966; Verner, 1974, 1987; Verner, Nikolaeva, 1997). From the middle of the 1960-s, a number of expeditions of such Moscow researchers as V.N. Toporov, B.A. Uspensky, S.A. Starostin, K.Iu. Reshetnikov were organized. In the 1980-s, a new alphabet of Ket language was developed. Due to the linguistic research carried out in the mid and late $20^{\text {th }}$ century, Ket language was revealed to be unique among other languages of the North and Siberia: "The Kets are a small ethnos, the language and origin of which is of great interest: being anthropologically different from their neighbours and finding features of far-away southern cultures in their lifestyle, they speak a unique language, that is not directly related to any other living language" (Dul'zon, 1968).

The key role in these processes was played by the linguistic policy of the Soviet Union.

Modern research of linguistic policy normally focuses on which functions of the language are supported by these or those solutions. Western researchers outline a language-making function, a function of constructing a language and implementing it into the everyday life of a nation, referred to as nation-building (Hirsch, 2005; Burbank, von Hagen, Remnev, 2007; Martin, Suni, 2011).

Soviet researchers defined this process as language-building, being the foundation of cultural revolution (Zak, Isaev, 1966). One of the leading sociolinguists of Russia, Vladimir Mikhailovich Alpatov, states that linguistic policy is tightly bound to the consideration and satisfaction of the basic needs satisfied in speech. According to his point of view, in its core meaning, language serves for satisfaction of two key needs of people that manifest themselves in speech: those are, the need for mutual understanding, reaching full contact with others, and the need for identity, which means self-identification in contact with others. At that, "both needs do not contradict each other, and are automatically satisfied in a completely monolingual community only" (Alpatov, 2000: 12). Since the unity of linguistic environment in countries and compact territories is more of an exception than an ordinary situation, the first need, the need for mutual understanding, mostly manifests itself in a heterogenous environment as a pursuit for bilingualism; at that, the need for identity is normally manifested through the desire for monolingualism, for speaking the mother tongue. There are six strategies of communication between speakers of different mother tongues, and the basic ones are three: development of a common contact language (pidgin), communication in a third language and communication in the mother tongue of one of the speakers. These strategies work to satisfy the key needs to a different extent. Thus, communication in a pidgin language satisfies the need for identity, though the need for mutual understanding is only partially fulfilled; speaking a third language satisfies only the need for understanding, ignoring the need for identity, while communication in the mother tongue of one of the speakers creates asymmetry, since the need for identity of only one speaker is fulfilled. Using the second strategy, the speakers are equal, but the common language prevails over their mother tongues; this is the common situation of relations the official language and the indigenous ones: "In colonies, it is the colonizers' language; in former colonies, it is that of former colonizers, and inside multilingual countries it is, most frequently, the dominating (official) language" (Alpatov, 2013: 13). At the stage of transition to industrial society, 
the main need is, inevitably, the need for mutual understanding. The main tool of satisfying the need for mutual understanding, that is the central need in the situation of integration of territories belonging to different peoples and transition to industrial society, is the common official language.

Moreover, V.M. Alpatov defines a language hierarchy that develops in multinational countries, describing it as an inverted pyramid consisting of three levels. The upper level is the monolingual official language speakers (e.g., Russian speakers in the USSR and modern Russia), the middle level is the bilingual citizens, and the lower level is the monolingual speakers of minority languages (or bilinguals who have no command of the official language). The researcher remarks that there is one similarity between this hierarchy and the social one: "the lower level of the linguistic hierarchy has a low social status. These are people engaged in agriculture and housekeeping, or nonassimilated immigrants" (Alpatov, 2013:16).

As noticed by Russian linguist V.M. Alpatov, historically dominant need of the state linguistic policy is to satisfy the need for mutual understanding and ignore the need for identity, which is supported though enforcing and spreading the official language (Alpatov, 2000). Enforcement of the official language includes two processes: spreading the language through administrative measures and school education (today, also through mass media), and codification of language, creation of common national linguistic norms. According to the researcher, an example of such large-scale linguistic policy is the policy of the Soviet government implemented in the 1920-1930$\mathrm{s}$, initially based on the central idea of equality of languages. In the first years after the Revolution, the policy was run by the People's Commissariat of Nationalities led by I.V. Stalin. In his article titled "Linguistic Policy in the Modern World: "Monolingual" and "Bilingual" Practices and
Linguistic Assimilation Problem", V.M. Alpatov quotes the words Stalin wrote in 1918: "No compulsory 'official' language, either in legal proceedings or at schools! Every province choses a language or languages, that suit the population of the province, following the principle of total equality of minority and majority languages, in all social and political institutions". He also refers to the report "National Issues in Party and Soviet Construction" of 1923, which calls for the Russian communists, working in ethnic regions, to stop using Russian language voluntarily (Alpatov, 2013: 11-22). This policy was a reaction to the tsar's policy of linguistic assimilation; it ended up in attempts to translate legal proceedings into languages of minorities or to popularize ethnic schools. The only factor that raised problems for running the policy is the insufficient level of development of the languages, many of which lacked codification, i.e. acknowledgment of the linguistic norms in dictionaries, grammar books, and rules, or even writing. V.M. Alpatov remarks, that this is the factor that underlaid language building, i.e. active work on creation of languages, and, particularly, efforts on development of writing and linguistic codification. During that period of time, the greatest Soviet linguists created over 70 new alphabets based on Latin. This work naturally became an integral part of the universal campaign on eradication of illiteracy that boosted the growth of education, also in ethnic languages. As Western Sovietologist Simon Crisp remarks, this is the achievement that even the most radical opponent of the Soviet system cannot but accept (Crisp, 1989: 36). At the same time, being a complete opposition to the previous one, the policy put aside the need for mutual understanding, which, along with the need for identity, forms the core of the needs satisfied by a language. This is why the researchers claim its success to be incomplete, accepting that the need for mutual understanding was satisfied in a chaotic manner. Eugeny Dmitrievich Polivanov, a famous 
linguist of those times, noticed the duality of the linguistic situation in the lives of students, resident in ethnic republics, indicating the strict division of the "influence zones" of the ethnic and the official languages. Taught in Russian, the young people used their mother tongue in their everyday life, and, therefore, had no interest, for example, in reading classic literature translated in their ethnic languages (Polivanov, 1927: 114). This way, the mother tongue was pushed into the sphere of everyday life, deprived of all other functions and situations of use. At the same time, V.M. Alpatov emphasizes the efficiency of the policy in relation to major language, demonstrating the example of an ethnic republic language. If, according to E.D. Polivanov, in the early 1920-s the identity of the settled Uzbeks was based merely on the place of birth and common religion, with literate people reading and writing in Old Turkish, Arabic or Russian (Polivanov, 1923: 9), then by the 1980-s every Uzbek identified himself as an Uzbek, which was greatly determined by the linguistic policy, and the majority of the nation was literate in Uzbek language.

The researchers mark the turning point of the Soviet linguistic policy of the late 1930-s, when the way of granting many functions to a minority language was replaced with an opposite one. According to them, the russification policy reached its peak in the late 1950-s - early 1960$\mathrm{s}$, when the idea of overcoming differences was established; as a result, there was hardly any education provided in the languages of ethnic minorities. The exception was the languages of the Union republics, but languages of the indigenous peoples of the North and Siberia Ket language belongs to, at that time were losing their influence in education and were again pushed back to the sphere of everyday life, dominated by the official language.

Therefore, two periods in the history of Ket language studies shall be outlined: the Soviet period (1930-1990-s) and the contemporary period (2000-s).

\section{Methods}

The present research is based on the methodological principles of historical analysis and historiographic approach.

Ket language is interesting for analysis since it has no direct connections to any of the presently existing languages, preserving its originality among other languages of the North and Siberia, represented in a number of dialects.

Analysis of the situation of the second half of the $20^{\text {th }}$ century and the early $21^{\text {st }}$ century is based on the findings of the researchers from M.V. Lomonosov Moscow State University (Kazakevich, 1994; Kazakevich, 2010), Tomsk State Pedagogical University (Dul'zon, 1966; Dul'zon, 1968; Dul'zon, 1972; Verner, 1974; Verner, 1987; Verner, 1999; Butorin, 2012 et al.) and Siberian Federal University (Krivonogov, 2003; Degtyarenko, 2015; Kistova, 2016; Zamaraeva, 2016; Berezhnova, 2018; Kirko, 2017; Kirko, 2015; Kolesnik, 2014; Pimenova, 2016; Reznikova, 2015 et al.), made within a series of grant projects and field expeditions in the Krasnoyarsk Territory (Krai) and the places of residence of the indigenous peoples.

\section{Ket language studies in the Soviet period}

In the Soviet period, Ket language, together with many others, was included into the project of creating writing for the small peoples, as they were called at that time. If after the 1980 -s, the efforts on creating writing for the languages of indigenous peoples were targeted at the preservation of the previously lost language links, in the early $20^{\text {th }}$ century, when the first Ket writing was created, the task of the scholars was to widen the functions performed by the indigenous languages. 
In the first two decades of the Soviet period, the majority of indigenous languages have been through two stages of development and establishment of writing: if in the 1920-s and the early 1930-s the new developed writing was based on Latin (as an opposition to the imperial Russian writing), by the end of the 1930 -s the intention of the state had changed and the alphabets were changed to be Cyrillic-based. V.M. Alpatov calls it a "focus on accelerated russification" (Alpatov, 2013). In that time, the Latin-based alphabets created for the small-numbered indigenous peoples of the Soviet Union just ten years ago were replaced with Cyrillic-based alphabets. In the process, a number of languages lost their writing at all; that is what happened to Ket language. It did not get its Cyrillic alphabet, and soon Ket language studies were ceased, since all the existing literature was written in the Latin version of the alphabet.

In the year 1930 in Leningrad the Institute of the Peoples of the North named after P.G. Smidovich (IPN) was opened to train teaching staff for the Extreme North areas; at the Institute, the Scientific and Research Association was founded. The Scientific and IPN Research Association, consisting of the best ethnographers and linguists, as well as the Institute students, who had been working on development of alphabets for languages with no writing, had presented a project of a unified Northern languages' Latinbased alphabet by the end of 1930, and introduced it at the All-Union Central Committee for Ethnic Alphabets that had been very active in that period of time (Tayga i tundra, 1932). As a result of the assessment and the amendments made by the ACCEA in the unified Northern languages' alphabet, the project was approved on February 23, 1931 (Prosveschenie na Sovetskom..., 1957). The first suggestion was to classify the indigenous peoples by the affinity of their languages, outlining one basic language for each group, for which the writing, serving as a foundation for the rest of the languages, will be made; the alternative was to transfer all peoples of the group to the basic language (Akhmetova, 2014).

The author of the Latin-based Ket alphabet is an ethnographer and linguist, Siberia researcher Nestor Konstantinovich Karger, who in the years 1928-1929 worked in expeditions to Ket settlements, including those to Turukhansk District of the Krasnoyarsk Territory (Krai). As a result of the field studies, in 1934 two books were published: "Ket Language" grammar book and the "ABC Book" (Karger, 1934). Moreover, during the expeditions, N.K. Karger made audio recordings, including those of Shaman rituals (Kolesnik, 2014). Since 1930, N.K. Karger had been a member of the Scientific Research Association of the newly created Institute of the Peoples of the North (former Workers' Faculty of Leningrad State University), also occupying the position of the Academic Secretary. The activity of the Association encompassed comprehensive studies of the indigenous peoples and the development of their languages; in the year 1928, it brought the official names of the indigenous Northern peoples into order, many of which had been purely random or had been put as nicknames. As a result, for instance, the people formerly known as the Yenisei people or the Yenisei Ostyaks were named Kets. N.K. Karger is known to have been actively working with the INP students, among which, since 1926, there were 3 Kets (Smirnova, 2012). Despite being the leading specialist in Ket language at that period of time, he got arrested, and after the term he never returned to the North studies again (Alpatov, 1990).

A North expert Yuri (Yerukhim) Abramovich Kreinovich, who continued his work even during his imprisonment term, is famous for his active linguistic and research. Before the arrest, he had been engaged in Nivkh language 
studies; imprisoned in a camp on the Kolyma, he learned Yukagir language, and during the second term of imprisonment he served in Yeniseisk District, he learned Ket language. The materials collected by him, were published after some time (Alpatov, 1990).

Despite such rich history of Ket language studies, the writing appeared only in the late 1980 -s. In 1988, the Ket language dictionary compiled by Genrikh Kasparovich Verner and Galina Kharlampyevna Nikolaeva (Verner, Nikolaeva, 1988), came out in Krasnoyarsk. In 1991, the book was also published in Leningrad. The official Ket language writing was approved in 1988 only. Thanks to the publishing of teaching aids, that recorded Ket language on the basis of Cyrillic writing, the language began to be taught at schools (Kazakevich, 1994).

In the 1990-s, the first teaching aids written by the same authors saw the light: Ket language textbooks for the $2^{\text {nd }}$ and the $3^{\text {rd }}$ grades, "Ket-Russian and Russian-Ket Dictionary. Primary School Teaching Aids". In 1999, in Krasnoyarsk, the first Ket reading book, prepared by G.K. Verner, was published: " $A b$ bisebdan i'l' (Song of My Brother). Epic Poem. Reading book for senior grades of Ket schools" (Verner, 1999). Another reading book compiled by G.Kh. Nikolaeva, was published in 2000, in Saint Petersburg: 'Der' knigan. Reading Book. Textbook for the $3^{\text {rd }}-4^{\text {th }}$ grades of Ket schools" (Nikolaeva, 2000).

This is why the 1990-s witnessed a boom of Ket language teaching. According to the data provided by the Okrug Directorate for Public Education in 1993, in Turukhansk District Ket language was taught to over 150 children, including primary school and senior grades (as a selective course) in Kellog Village, as well as primary school students in villages Goroshikha, Vereschagino, Surgutikha, Baklanikha and Sulomay (Kazakevich, 1994).

\section{Modern situation in Ket language studies}

Today's situation evidences disappearance of the language from everyday communication practice of the indigenous population of the Krasnoyarsk Territory (Krai). Researchers notice, that the mother tongue is only spoken by the senior generation and some middleaged people; the new generation studies mother tongue at primary school, and later it is taught as a selective course (Pustogacheva, 2014). An ethnographer from Krasnoyarsk, Victor Pavlovich Krivonogov, carried out a monitoring research to find consistent decline in the share of Ket ethnos representatives, who maintain a good command of Ket language and claim it to be their mother tongue (Krivonogov, 2003). Today, Ket language is acknowledged as a rapidly disappearing one (Yazyki narodov Sibiri, nakhodiaschiesia pod ugrozoy ischeznoveniia); information on Ket language has been placed in the corresponding section on the website of the Institute of Ethnography and Anthropology of the Russian Academy of Sciences "Threatened Languages of Siberian Peoples".

Ket language attracts interest of a number of research centres besides the Institute for Linguistic Studies of RAS (Saint Petersburg) or specialists from Russian State University for the Humanities (Moscow), Herzen State Pedagogical University of Russia (Saint Petersburg), United Institute for History, Philology, and Philosophy of the RAS (Novosibirsk), Tomsk State Pedagogical University, Bonn University (Germany).

The works by American linguist Edward Vajda from Western Washington University, who had been studying Ket language and running field studies in Turukhansk District of the Krasnoyarsk Territory (Krai) until 2008, are widely known (Vajda, 2001). The scholar came up with his own concept of grammatical description for Ket language. 
A relevant project on comprehensive records of Ket language is run by the specialists from the Laboratory for Computational Lexicography of Research Computing Centre of Lomonosov Moscow State University, led by a linguist, Candidate of Philology Olga Anatolyevna Kazakevich (Laboratory for Computational Lexicography of Moscow State University). The researcher group of the laboratory carries out field studies on a regular basis. Starting from the year 1996, O.A. Kazakevich has been heading a number of projects that allowed to develop a common concept for efficient records of language data and to create multimedia databases for Ket, Selkup and Evenki languages (Internet source: "Small languages of Siberia: our cultural heritage"). It contains a corpus of materials on Ket language, including both verbal materials, like dictionaries and texts, and video materials, photographs and language games for studying various accents. At that, Selkup and Evenki language sections contain voiced dictionaries, that the Ket language section still lacks.

\section{Conclusion}

The present research leads us to the following conclusions.

First of all, Ket language is one of the most complicated and interesting indigenous languages, the origin of which is still not clear, with a variety of dialects that serve as a rich material for new concepts of grammar descriptions.

Secondly, we should remark that the greatest success in Ket language studies was achieved by Soviet scholars of the middle and late $20^{\text {th }}$ century, who created a writing and a linguistic base for teaching the language at schools.

Thirdly, Ket language has had two alphabets created for it: Latin and Cyrillic-based, but neither of them has become a foundation for the enforcement and popularization of the language among the representatives of the ethnos, which is directly related to the linguistic policy of the Russian state during the Soviet period.

Fourthly, modern researchers claim that Ket language is likely to extinct in the nearest future, since there is no need, objective or opportunity to use this language in the everyday life of the small-numbered ethnos.

Fifthly, during more than 100 years of Ket language studies a great material has been collected and arranged to "museumify" it and continue its studies even after it ceases its existence as a living language.

Sixthly, to preserve Ket language as a living language of communication, there is a clear urge to broaden the available range of materials, teaching aids, as well as literature published in Ket language.

\section{References}

Akhmetova, A.V. (2014). Problems in Creating Written Language for the Small Native Peoples of the Far East in the Second Half of the 1920s-1930s, In: Bylye gody. Rossiyskiy istoricheskiy zhurnal [Russian Historical Journal], 31 (1), 13-18.

Alexeenko, E.A. (1967). Kety: istoriko-etnograficheskie ocherki $[$ Kets: Historical and Ethnographic Essays]. Moscow.

Alpatov, V.M. (1990). Martirolog vostokovednoy lingvistiki [Martyrology of Oriental Linguistics], In: Vestnik AN SSSR [Newsletter of the USSR Academy of Sciences], Moscow.

Alpatov, V.M. (2000). 150 iazykov i politika. 1917-2000 [150 Languages and Politics], In: Sotsiolingvisticheskie problemy SSSR i postsovetskogo prostranstva [Sociolinguistic Problems of the USSR and the Post-Soviet Space]. Moscow. 
Alpatov, V.M. (2013). Iazykovaia politika v sovremennom mire: "odnoiazychnaia" i "dvuiazychnaia" praktiki i problema iazykovoy assimiliatsii [Linguistic Policy in the Contemporary World: "Monolingual" and "Bilingual" Practices and Linguistic Assimilation Problem], In: Sravnitel'naia politika [Comparative Politics], 4(2(12)).

Andreeva, O.A. (2009). Ideograficheskiy analiz leksiki kak sposob vyiavleniia kontseptov ketskoy kartiny mira [Ideographic Vocabulary Analysis as a Means of Detecting Concepts of the Ket World Outlook], In: Vestnik Tomskogo gosudarstvennogo universiteta [Toms State University Newsletter], 323.

Berezhnova, M.I., Pimenova, N.N. (2018). Istoriia formirovaniia subetnosa esseyskikh iakutov (na materiale analiza nauchnykh issledovaniy i arkhiva Krasnoiarskogo kraevogo kraevedcheskogo muzeia) [Development History of the Essey Yakuts (Based on the Research and Archives of Krasnoyarsk Regional Museum of Regional Studies)], In: Severnye narody i ekspeditsii [Northern Peoples and Expeditions], 4, 30-52.

Bulatova, N.Ia., Vakhtin, N.B., Nasilov, D.M. (1997). Iazyki malochislennykh narodov Severa [Languages of the Small-Numbered Peoples of the North], In: Malochislennye narody Severa, Sibiri $i$ Dal'nego Vostoka: problemy sokhraneniia i razvitiia iazykov [Small-Numbered Peoples of the North, Siberia and the Far East: Language Development and Preservation Problems], 6-27.

Burbank, J., von Hagen, M., Remnev, A. (2007). Russian empire: space, people, power, 17001930. Indiana University Press.

Butorin, S.S. (2012). Direktivnye glagol'nye satellity v ketskom iazyke i tipologiia modeley leksikalizatsii L. Talmi [Directive Verbal Satellites in Ket Language and Typology of L. Talmi Lexicalization Models], In: Vestnik Tomskogo gosudarstvennogo pedagogicheskogo universiteta [Tomsk State Pedagogical University Newsletter], 1.

Castrén, M.A. (1858). Versuch einer jenissei-ostjakischen und kottischen Sprachlehre. St. Petersburg.

Crisp, S. (1989). Soviet Language Planning. 1917-1953. In: Language Planning in the Soviet Union. London.

Degtiarenko, K.A. (2015). Aktual'noe sostoianie korennykh malochislennykh narodov Severa [Current Condition of the Small-Numbered Indigenous Peoples of the North], In: Sotsiodinamika [Sociodynamics], 10, 39-57.

Dul'zon, A.P. (1966). Ketskie skazki [Ket Fairy Tales]. Tomsk University Press.

Dul'zon, A.P. (1968). Ketskiy iazyk [Ket Language]. Tomsk University Press.

Dul'zon, A.P. (1972). Skazki narodov sibirskogo severa [Fairy Tales of the Peoples of Siberian North], Vol. 1. Tomsk University Press.

Hirsch, F. (2005). Empire of Nations. In: Ethnographic Knowledge and the Making of the Soviet Union. Cornell University Press.

Internet portal "Threatened Languages of the Siberian Peoples" of the Institute of Ethnography and Anthropology of the RAS. Available at: lingsib.iea.ras.ru/

Karger, N.K. (1934). Bukvar. Leningrad.

Kazakevich, O.A. (1994). Iazykovaia situatsiia u korennykh malochislennykh narodov Turukhanskogo rayona: kety i sel'kupy [Linguistic Situation of the Small-Numbered Indigenous Peoples of Turukhansk District: the Kets and Selkups], In: Iazyk v kontekste obschestvennogo razvitiia [Language in the Context of Social Development]. Moscow, 110-123. 
Kazakevich, O.A. (2010). Evenkiysko-ketskaia ekspeditsiia 2009 g.: dokumentatsiia iazykov i dialektov, kotorye mogut ischeznut' [Evenki-Ket Expedition 2009: Documentation of the Languages and Dialects That May Extinct], In: Vestnik Rossiyskogo gumanitarnogo nauchnogo fonda [Newsletter of the Russian Scientific Foundation for the Humanities]. No. 3. P. 206-212.

Karger, N.K. (1934). Ketskiy iazyk [Ket Language], In: Iazyki i pis'mennost' narodov Severa [Languages and Writing of the Northern Peoples], Vol. III - Moscow.

Kirko, V.I., Kuznetsova, Iu.S., Malakhova, E.V., Vasilyev, E.A. (2017). Otsenka kachestva zhizni zhiteley rayona Arkticheskoy zony na primere posiolka Respubliki Sakha (Iakutiia) [Evaluation of the Living Standards of the Arctic Zonde Residents Based on a Settlement in the Republic of Sakha (Yakutia)], In: Severnye arkhivy i ekspeditsii [Northern Archives and Expeditions], 3, 21-37.

Kirko, V.I. (2015). Postsovetskie praktiki sokhraneniia etnokulturnoy identichnosti korennykh narodov Severa i Sibiri v Krasnoiarskom krae Rossiyskoy Federatsii [Post-Soviet Practices of Preserving Ethnocultural Identity of the Indigenous Peoples of the North and Siberia in the Krasnoyarsk Territory of the Russian Federation], In: Sotsiodinamika [Sociodynamics], 6, 113-133.

Kistova, A.V., Zamaraeva, J.S., Pimenova, N.N., Reznikova, K.V., Koptseva, N.P., Seredkina, N.N. (2016). Regional Peculiarities in Modernization Processes within the Territories of Central Siberia. International Review of Management and Marketing, 6(4), 857-865.

Klokov, K.B. (1997). Traditsionnoe prirodopol'zovanie narodov Severa: kontseptsiia sokhraneniia i razvitiia: monografiia [Traditional Nature Use of the Siberian Peoples: Preservation and Development Concept: Monograph], Saint Petersburg.

Kolesnik, M.A. (2014). Obzor izucheniia fol'klora korennykh narodov Severa [Review of the Studies of Folklore of the Indigenous Northern Peoples]. Litera, 3, 39-59.

Korennye malochislennye narody Severa i Sibiri v usloviiakh global'nykh transformatsiy (na materiale Krasnoiarskogo kraia) [Small-Numbered Indigenous Peoples of the North and Siberia in the Global Transformations (Based on the Krasnoyarsk Territory (Krai)] (2012). Vol. 1, Krasnoyarsk.

Kotorova, E.G., Porotova, T.I. (2001). Ketskiy iazyk v krugu ischezayuschikh iazykov i zadachi ego leksikograficheskogo opisaniia [Ket Language in the Circle of Extincting Languages and the Tasks of Lexicological Description], In: Mezhdunarodnoe izuchenie etnosov Sibiri [International Studies of Siberian Ethnicities]. Tomsk, Tomsk State Pedagogical University, 4-14.

Kreynovich, E.A. (1968a). Ketskiy iazyk [Ket Language], In: Iazyki narodov SSSR [Languages of the USSR Peoples], Vol. 5, 453-473.

Kreynovich, E.A. (1968b). Glagol ketskogo iazyka [Ket Verbs]. Leningrad.

Kreynovich, E.A. (1969). Medvezhiy prazdnik u ketov. Ketskiy sbornik. Morfologiia, etnografiia, teksty [Bear Celebration of Kets. Ket Collection: Morphology, Ethnography, Texts]. Moscow, 6-112.

Krivonogov, V.P. (2003). Kety: desiat' let spustia (1991-2001 gg.) [Kets: Ten Years After (19912001)]. Krasnoyarsk.

Martin, T., Suni, R.G. (2011). Gosudarstvo natsiy: imperiia i natsional'noe stroitelstvo v epokhu Lenina i Stalina [State of Nations: the Empire and Nation Building in the Lenin and Stalin Eras]. Moscow.

Nikolaeva, G.Kh. (2000). Der' knigan. Kniga dlia chteniia. Uchebnik dlia 3-4 klassov ketskikh shkolk [Der' Knigan. Reading Book. Textbook for the $3^{\text {rd }}-4^{\text {th }}$ Grades of Ket Schools]. Saint Petersburg.

Novoe buduschee Sibiri: ozhidaniia, vyzovy, resheniia [New Future of Siberia: Expectations, Challenges, Solutions] (2013). Krasnoyarsk. 
Official Internet portal of the Laboratory for Computational Lexicography of Research Computing Centre of Lomonosov Moscow State University. Available at: http://www.lcl.srcc.msu.ru/index.htm

Official Internet portal of the project "Creating the Internet Source 'Small languages of Siberia: our cultural heritage' (Based on Languages of the Central Yenisei and the Central and Upper Taz Basins)”. Available at: http://minlang.srcc.msu.ru/ru/glavnaya

Pallas, P.S. (1786). Puteshestvie po raznym mestam Rossiyskogo gosudarstva [A Travel Through Various Provinces of the Russian Empire]. Saint Petersburg.

Pimenova, N.N (2016). Mekhanizmy sotsiokul'turnykh izmeneniy korennykhh malochislennykh narodov Sibiri i Severa: kontseptsiia kul'turnoy travmy P. Shtompki [Sociocultural Changes Dynamics of the Small-Numbered Indigenous Peoples of Siberia and the North: P. Shtompka Cultural Trauma Concept], In: Sotsiodinamika [Sociodynamics], 3, 37-45.

Polivanov, E.D. (1923). Problema latinskogo alfavita v turetskikh pis'mennostiakh [Latin Alphabet Problems in Turkish Writings]. Moscow.

Polivanov, E.D. (1927). Rodnoy iazyk v natsional'noy partshkole [Mother Tongue at an Ethnic Communist Party School], In: Voprosy natsional'nogo partprosvescheniia [Ethnic Communist Party Indoctrination Issues]. Moscow.

Project "Main Trends of Cultural Policy Strategy of the Krasnoyarsk Territory (Krai) for the Years 2009-2020”: Official Internet Portal of the Krasnoyarsk Territory (Krai). Access: http://www. krskstate.ru/dat/bin/art_attach/312_koncept.doc (accessed on 11.06.2017)

Prosveschenie na Sovetskom Kraynem Severe [Enlightenment in the Soviet Extreme North]. Leningrad.

Pustogacheva, A.F. (2014). Sovremennnoe sostoianie obucheniia i izucheniia rodnykh iazykov korennykh malochislennykh narodov Severa, Sibiri i Dal'nego Vostoka v sisteme obrazovaniia Rossiyskoy Federatsii [Current Condition of Teaching and Studies of the Mother Tongues of the SmallNumbered Indigenous Peoples of the North, Siberia and the Far East in the Education System of the Russian Federation], In: Istoriia i pedagogika estestvoznaniia [History and Pedagogy of Natural Science], 2, 41-46.

Ragulina, M.V.(2000). Korennyeetnosy Sibirskoytaygi: motivatsiia istrukturaprirodopol'zovaniia (na primere tofalarov $i$ evenkov Irkutskoy oblasti): monografiia [Indigenous Ethnicities of Siberian Tayga: Motivation and Structure of Nature Use (Based on the Tofalars ad Evenkis of Irkutsk Oblast): Monograph], Novosibirsk.

Reznikova, K.V. (2015). Sokhraneniie traditsionnykh iazykov korennykh malochislennykh narodov kak obespechenie osnovy kul'turnogo raznoobraziia regiona [Preservation of Traditional Languages of the Small-Numbered Indigenous Peoples as a Forming the Basis for Cultural Diversity of the Region], In: Sovremennye problemy nauki i obrazovaniia [Modern Problems of Science and Education], (1-1).

Reznikova, K.V., Pimenova, N.N., Kistova, A.V., Seredkina, N.N., Zamaraeva, Iu.S. (2016). Upravlenie brendingom sibirskoy territorii v svete "novogo regionalizma" [Siberian Territory Branding Management in the Context of "New Regionalism"]. Sotsiodinamika [Sociodynamics] 1, 137-161.

Sever i severiane. Sovremennoe polozhenie korennykh malochislennykh narodov Severa, Sibiri i Dal'nego Vostoka Rossii [North and the Northern People: Current Condition of the Small-Numbered Indigenous Peoples of the North, Siberia and the Far East of Russia] (2012).

$$
-543-
$$


Smirnova, T.M. (2012). Institut narodov Severa v Leningrade - uchebnoe zavedenie novogo tipa [Leningrad Institute of the Northern Peoples: New Format of an Education Institution], In: Vestnik LGU im. A.S. Pushkina [A.S. Pushkin Leningrad State University Newsletter], 2, Vol. 4, 51-65.

Sovremennoe polozhenie i perspektivy razvitiia malochislennykh narodov Severa, Sibiri $i$ Dal'nego Vostoka [Current Condition and Development Prospects of the Small-Numbered Peoples of the North, Siberia and the Far East] (2004).

Tayga i tundra: izdanie kraevedcheskogo kruzhka Instituta narodov Severa [Tayga and Tundra: Title of the Circle of Regional Studies of the Institute of the Northern Peoples] (1932). Leningrad, 4.

Vajda, Ed.J. (2001). Yeniseian peoples and languages. In: A history of Yeniseian studies with an annotated bibliogfaphy and a source guide. Curzon.

Verner, G.K. (1974). Reliktovye priznaki aktivnogo stroia v ketskom iazyke [Relict Active Structure Features in Ket Language], In: Voprosy iazykoznaniia [Linguistic Issues], 1, 170-179.

Verner, G.K. (1987). Novyy ketskiy alfavit i nekotorye metodicheskie rekomendatsii po vvedeniiu v praktiku raboty ketskoy shkoly [New Ket Alphabet and Some Methodological Recommendations on Alphabet Implementation into Ket School Practice], In: Story samodiyskikh i eniseyskikh iazykov [Structure of Samoyed and Yenisei Languages]. Tomsk, 86-93.

Verner, G.K. (1999). Ab-bisebdan-i'l' (Pesn' o moiom brate). Epicheskaia poema. Kniga dlia chteniia $v$ starshikh klassakh ketskikh shkol [Ab-bisebdan-i'l' (Song of My Brother). Epic Poem. Reading Book for Seniour Grades of Ket Schools]. Krasnoyarsk.

Verner, G.K., Nikolaeva, G.Kh. (1988). Ostyngynna bukvar' (ketskiy eksperimental'nyy slovar') [Ostyngynna ABC Books (Ket Experimental ABC Book)]. Krasnoyarsk.

Verner, G.K., Nikolaeva, G.Kh. (1997). Ketskiy iazyk [Ket Language], In: Iazyki Rossiyskoy Federatsii i sosednikh gosudarstv [Languages of the Russian Federation and the Neighbouring States].

Vinokurova, L.I. (2003). Sever: etnosy, obschestvo, chelovek: monografiia [The North: Ethnicities, Society, Person: Monograph], Yakutsk.

Zak, L.M., Isaev, M.I. (1966). Problemy pis'mennosti narodov SSSR v kul'turnoy revoliutsii [The USSR People's Writing Problems in the Cultural Revolution], In: Voprosy istorii [History Issues], 2, February, 3-20.

Zamaraeva, Iu.S., Koptseva, N.P., Reznikova, K.V., Seredkina, N.N (2016). Regional'naia spetsifika sotsial'nykh tsennostey i ikh vliianie na protsessy modernizatsii territoriy Tsentral'noy Sibiri (na materiale issledovaniy Krasnoiarskogo kraia [Regional Specificity of Social Values and Their Influence on Modernization Processes of the Central Siberian Territories (Based on the Research of the Krasnoyarsk Territory (Krai)], In: Економічий часопис-XXI, 160, 92-95. 


\title{
Историография кетского языка
}

\author{
А.В. Кистова, Н.Н. Пименова \\ Сибирский федеральный университет \\ Россия, 660041, Красноярск, пр. Свободный, 79
}

Статья рассматривает историю изучения языков коренных малочисленных народов Севера и Сибири, в частности кетского языка. Определяются основные этапы истории исследования кетского языка в дореволюиионный, советский и современный периоды. Рассматриваются результаты экспедиций, выявляющих проблемы существования и возможности сохранения языка кетов. Описаны результаты изучения кетского языка специалистами. Делаются выводы о текущуем положении этой области знания в Сибири, России и за ее пределами, обозначаются возможные перспективы.

Ключевые слова: изучение языков коренных малочисленных народов Севера и Сибири, кетский язык, полевые исследования, лингвисть-этнографы.

Исследование выполнено при поддержке Красноярского краевого фонда науки в рамках реализачии проекта: «Разработка научно-методического обеспечения сохранения уникального культурного наследия для кетской и энецкой этнокультурных групп коренных малочисленных народов Севера, Сибири и Дальнего Востока, проживающих на территории Красноярского края.

Научная специальность: 24.00.00 - культурология. 